\title{
Molecular Markers of Neuronal Progenitors in the Embryonic Cerebellar Anlage
}

\author{
Daniver Morales and Mary E. Hatten \\ Laboratory of Developmental Neurobiology, The Rockefeller University, New York, New York 10021-6399
}

\begin{abstract}
The cerebellum, like the cerebrum, includes a nuclear structure and an overlying cortical structure. Experiments in the past decade have expanded knowledge beyond the traditional function of the cerebellum to include critical roles in motor learning and memory and sensory discrimination. The initial steps in cerebellar development depend on inductive signaling involving FGF and Wnt proteins produced at the mesencephalic/metencephalic boundary. To address the issue of how individual cerebellar cell fates within the cerebellar territory are specified, we examined the expression of transcription factors, including mammalian homologues of LIM homeodomaincontaining proteins, basichelix-loop-helix proteins, and three amino acid loop-containing proteins. The results of these studies show that combinatorial codes of transcription factors define precursors of the cerebellar nuclei, and both Purkinje cells and granule neurons of the cerebellar cortex. Examination of gene expression patterns in several hundred lines of $E g f p$-BAC (bacterial artificial chromosome) transgenic mice in the GENSAT Project revealed numerous genes with restricted expression in cerebellar progenitor populations, including genes specific for cerebellar nuclear precursors and Purkinje cell precursors. In addition, we identified patterns of gene expression that link granule and Purkinje cells to their precerebellar nuclei. These results identify molecular pathways that offer new insights on the development of the nuclear and cortical structures of the cerebellum, as well as components of the cerebellar circuitry.
\end{abstract}

Key words: cerebellar histogenesis; cerebellar nuclei; Purkinje cells; granule cells; transcription factors; embryonic

\section{Introduction}

The cerebellum, like the cerebrum, contains an outer cortical structure, a layer of white matter, and a set of cerebellar nuclei (CNPs) beneath the white matter. The cerebellar nuclei, like the basal ganglia of the forebrain, control the execution of smooth coordinated movements. The cortex contains two principal neurons, the Purkinje cell (PC) and the granule cell, arranged in a nearly crystalline, laminar array (Palay and Chan-Palay, 1974). The granule neuron receives inputs from mossy fibers from various parts of the brain, including the lateral pontine nucleus (Eccles et al., 1967; Palay and Chan-Palay, 1974; Ito, 2006). Granule cell parallel fiber excitation and ascending axonal inhibition of the Purkinje cell are the principal elements of the cerebellar circuitry (for review, see Bower, 2002). The Purkinje cell is the sole output neuron of the cerebellar cortex, via connections with neurons in the cerebellar nuclei, which project efferent fibers to the thalamus, brainstem, and spinal cord (Cholley et al., 1989;

Received Aug. 25, 2005; revised Sept. 28, 2006; accepted Sept. 29, 2006.

This work was supported by a Presidential fellowship from Chile (D.M.), National Institutes of Health (NIH) Grant NS R01 30532-04 (M.E.H.), and NIH-National Institute of Neurological Disorders and Stroke Contract N01 NS02331 (Nathanial Heintz and M.E.H.).We thank Tom Jessell, A. Buchberg, A. Goffinet, and M. Yamamoto for generously providing antibodies and T. Jessell, $Q$. Ma, and M. Torres for in situ probes. The Gene Expression Nervous System Atlas Project [Drs. N. Heintz and M.E.H. (Co-Principal Investigators), The Rockefeller University, New York, NY] generated the $B A C$ mice used in this study, and we are grateful to the staff for their assistance. We especially thank Dr. Ana Milosevic for her expert help and advice on the GENSAT data reported in this manuscript; Tom Jessell, Cori Bargmann, and Ali Hemmati-Brivanlou for helpful discussions; Kathyrn Zimmerman for critically reading this manuscript; and Michael Morris for help with preparing the figures for this manuscript.

Correspondence should be addressed to Mary E. Hatten at the above address. E-mail: hatten@rockefeller.edu. D0I:10.1523/JNEUROSCI.3493-06.2006

Copyright $\odot 2006$ Society for Neuroscience ～0270-6474/06/2612226-11\$15.00/0
Teune et al., 2000). Because experiments to trace the commitment of cells to specific fates in other systems, most notably spinal cord, have revealed key insights on the mechanisms underlying physiology and connectivity, defining the genes that specify different types of neurons in the cerebellar cortex and the cerebellar nuclei should provide insight on the development of the cerebellar system.

During embryogenesis, the vertebrate hindbrain is transiently segmented into neural segments termed rhombomeres between embryonic day 8.5 (E8.5) to E9.5 in the mouse and stages 9-12 in the chick (Fienberg et al., 1987; Fraser et al., 1990; Krumlauf et al., 1993). The borders of the rhombomeres align with the borders of expression of specific Hox genes (Wilkinson et al., 1989). In chick, the cerebellar territory arises from rhombomere 1, delineated by the expression of Hoxa2 (posterior) and Otx2 (anterior) (Wingate and Hatten, 1999). In both mouse and chick, expression of Fgf8 in the isthmus "organizes" the patterning of the cerebellum (Martinez et al., 1999) by maintaining the expression of Otx2 and Gbx1 (Joyner et al., 2000). Negative interactions between $O t \times 2$ and $G b \times 2$ provide the boundary of the cerebellar territory and the midbrain.

In the mouse, neural tube closure is complete by E9.5, except for several areas, including the area at the border of mesencephalon and metencephalon, the rhombic lip. Both fate-mapping experiments and transplantation experiments have concluded that the anterior rhombic lip (aRL) gives rise to the precursors of the granule neuron of the cerebellum, the most abundant neuron in the brain, and neurons of the precerebellar nuclei and the olivary nucleus (Essick, 1912; Palay and Chan-Palay, 1974; Millen et al., 1999; Rodriguez and Dymecki, 2000; Sotelo, 2004). Classi- 
cal studies indicate that the ventricular zone (VZ) along the fourth ventricle generates neurons of the cerebellar nuclei, the principal output neuron of the cerebellar cortex, the Purkinje cell, and cerebellar interneurons (Palay and Chan-Palay, 1974; Laine and Axelrad, 1994; Dino et al., 2000; Nunzi et al., 2001; Laine and Axelrad, 2002). More recent studies show that neurons of the cerebellar nuclei (Wang et al., 2005; Fink et al., 2006) and of the hindbrain nuclei of the "cerebellar system" (Dymecki and Tomasiewicz, 1998; Wingate and Hatten, 1999; Machold and Fishell, 2005; Wang et al., 2005) are also generated from progenitors located in the anterior rhombic lip, the source of cerebellar cortical granule neurons (Hallonet et al., 1990; Alder et al., 1996)

Combinations of transcription factors (TFs) play pivotal roles in CNS neuronal specification. Several classes of transcription factors are required for the development of the cerebellum, including mammalian homologues of Hox genes, Paired-box (PAX) genes, Pou genes, basic helix-loop-helix (bHLH) genes, and LIM (the three gene products LIN-11, ISL-1, and MEC-3) homeodomain-containing genes (Shirasaki and Pfaff, 2002). Negative interactions between the Pax genes, Pax6 and Pax2 and the Homeobox gene, En1/2, are essential for cerebellar patterning because of their maintenance of the midbrain/hindbrain boundary (Joyner, 1996). Among Pou genes, Pit is essential for cerebellar development because of its control of a specific pituitary protein that activates genes that encode growth hormones (Hoshino et al., 2005). The bHLH gene Math1 is essential for granule cell development (Ben-Arie et al., 1997), and recent lineage tracing experiments show that Math1+ cells in the rhombic lip also generate neurons in the cerebellar nuclei, the lateral pontine nucleus, and the cochlear nucleus (Wingate and Hatten, 1999; Machold and Fishell, 2005; Wang et al., 2005).

To study the previous specification of neurons of the cerebellar nuclei and the cerebellar cortex, we examined the expression of major families of transcription factors in both the mouse and the chick. In addition, to assay gene expression at multiple stages of cerebellar development and to enable real time studies of cell migration, we generated the following bacterial artificial chromosome (BAC) transgenic mice that express an enhanced green fluorescent protein (EGFP) reporter protein: $L h x 1, L h \times 2, L h \times 5$, Lhx9, Irx3, Meis1, Meis2. We also screened several hundred lines of BAC transgenic mice generated in the GENSAT project for genes expressed in the cerebellum at E15.5. The results of these studies provide evidence that postmitotic precursors of neurons of the cerebellar nuclei express the transcription factors Lhx2/9, Meis $1 / 2$, and Irx3. Other genes expressed in cerebellar nuclei at E15.5 include Gap junction membrane channel protein $\alpha 9$ (Gja9), Methyl-Cpg-binding domain protein 2 (Mbd2), 5-hydroxytryptamine (serotonin) receptor $3 a(H \operatorname{tr} 3 a)$, and the G-protein inward rectifying channel gene (Girk4), providing other novel markers for neurons of the cerebellar nuclei. Cortical Purkinje neurons expressed the LIM transcription factors LHX1, LHX5, and RGS8, a GTPase-activating protein. Granule neurons and their precerebellar nuclei are marked by Math1, Pde1c, and Pcsk9 expression. Our results demonstrate that combinatorial patterns of transcription factor expression mark progenitors of the cerebellar nuclei and the Purkinje cells and illustrate the complex migrations that generate the nuclear and cortical regions of the cerebellum.

\section{Materials and Methods}

Animals. C57BLJ/6 and FVB/N mice were housed in the Rockefeller University animal facility on a $12 \mathrm{~h}$ light/dark cycle. Timed pregnancies were established by checking vaginal plugs every morning, with the day of the sperm impregnation being designated E0.5. Embryos were collected between stages E10 and E16.5 from anesthetized pregnant dams. Postnatal day 6 (P6) and adult mice were also analyzed. The generation of Irx3, Math1, Lhx1, Lhx5, and Pcp2 BAC transgenic mouse lines carrying the EGFP gene reporter was done following procedures reported by Gong et al. (2003). Fertilized White Leghorn (Gallus gallus) chicken eggs (Spafas, North Franklin, CT) were incubated at $37.5^{\circ} \mathrm{C}$ with a relative humidity of $90 \%$ in a circulated air incubator (GQF Manufacturing, Savannah, GA). The first day of incubation is designated as E0. Embryos were collected between stages E4 (HH23) and E7 (HH31) (Hamburger and Hamilton, 1992).

Immunohistochemistry. Embryos were fixed by immersion in 4\% paraformaldehyde in PBS at $4^{\circ} \mathrm{C}$. For immunostaining on postnatal and adult brains, the animals were anesthetized with Nembutal and fixed by transcardial perfusion of $4 \%$ paraformaldehyde/PBS. Cryostat sections were blocked for $1 \mathrm{~h}$ in PBS containing 3-5\% NGS and 0.1\% Triton X-100. Incubation with primary antibodies was done at $4^{\circ} \mathrm{C}$ overnight, followed by rinses in PBS and incubation with secondary antibodies for $1 \mathrm{~h}$ at room temperature. Fluorescent-conjugated secondary antibodies were used to detect the primary antibodies (Jackson ImmunoResearch, West Grove, PA; Invitrogen, San Diego, CA). The primary antibodies used in this study were as follows: rabbit anti-Lhx1/5, rabbit anti-Lhx2/9, and rabbit anti-Irx3 (gift from Dr. T. M. Jessell, Columbia University, New York, NY); rabbit anti-Meis1 and rabbit anti-Meis2 (gift from Dr. A. Buchberg, Thomas Jefferson University, Philadelphia, PA); mouse antiReelin (gift from Dr. A. Goffinet, University of Louvain, Brussels, Belgium); rabbit anti-brain lipid-binding protein (BLBP) (gift from Dr. N. Heintz, The Rockefeller University, New York, NY); mouse anti-RC2 (gift from Dr. M. Yamamoto, University of Tsukuba, Tsukuba, Japan); mouse anti-Calbindin (Swant, Bellinzona, Switzerland); mouse antiTuj1 (class III $\beta$-tubulin) (Covance, Santa Cruz, CA); rabbit anti-EGFP (Invitrogen); and sheep anti-EGFP (Biogenesis, Sandown, NH). Images were collected on a Zeiss (Thornwood, NY) fluorescence microscope using a SPOT camera (Diagnostic Instruments, Sterling Heights, MI) or a Radiance 2100 confocal microscope (Bio-Rad, Hercules, CA).

RNA in situ hybridization. In situ hybridization on whole-mount brains or tissue sections was performed as described by Sanders et al. (2002). Briefly, embryos were fixed in $4 \%$ paraformaldehyde/PBS at $4{ }^{\circ} \mathrm{C}$ overnight. Samples were incubated in detergent solution and then postfixed with $4 \%$ paraformaldehyde/PBS. RNA probes synthesized using digoxigenin-labeled nucleotides (Roche, Indianapolis, IN) were diluted in hybridization solution (50\% formamide, $5 \times$ SSC, $2 \%$ SDS, $500 \mu \mathrm{g} / \mathrm{ml}$ tRNA, 2\% Boehringer blocking reagent, and $50 \mu \mathrm{g} / \mathrm{ml}$ heparin) and applied at $70^{\circ} \mathrm{C}$ overnight. After hybridization, the samples were washed first in solution X ( $50 \%$ formamide, $2 \times$ SSC, and $1 \%$ SDS) and then with TBST ( $25 \mathrm{~mm}$ Tris HCl, pH 7.5, $136 \mathrm{~mm} \mathrm{NaCl}, 2.68 \mathrm{KCl}$, and 1\% Tween 20). Probes to cMeis1 (Dr. M. Torres, Centro Nacional de Biotecnologia, Madrid, Spain), cIrx3 (T. Jessell), and Math1 (Dr. Q.-F. Ma, Dana-Farber Cancer Institute, Boston, MA) were detected with alkaline phosphataseconjugated anti-digoxigenin antibody. Color reactions were performed with the substrates for alkaline phosphatase 5-bromo-4-chloro-3indolyl-phosphate and tetranitroblue tetrazolium chloride.

5-bromo-2'-deoxyuridine staining. Pregnant mice were injected intraperitoneally with a solution of 5-bromo- $2^{\prime}$-deoxyuridine (BrdU) in water between E10 and E11.5 (Sigma; $50 \mu \mathrm{g} / \mathrm{g}$ body weight). Cryostat sections were incubated in $2 \mathrm{~N} \mathrm{HCl}$ at $37^{\circ} \mathrm{C}$ for $30 \mathrm{~min}$, rinsed in $\mathrm{PBS}$, and incubated in $0.1 \mathrm{M}$ boric acid, $\mathrm{pH} 8.5$, for $10 \mathrm{~min}$. The sections were blocked for $1 \mathrm{~h}$ in PBS with 10\% normal goat serum and $0.1 \%$ Triton $\mathrm{X}-100$, followed by incubation with anti-BrdU monoclonal antibody (Beckton Dickinson, Mountain View, CA) in 5\% NGS at $4^{\circ} \mathrm{C}$ overnight. For fluorescent detection, we used $\mathrm{Cy} 3$ and FITC-conjugated secondary antibodies.

Egfp-BAC transgenic mice. Egfp-BAC transgenic mice used in this study were kindly provided by the NIH GENSAT Project (Gong et al., 2003). The expression pattern of EGFP in BAC transgenic mice was confirmed by parallel in situ hybridization experiments in the BGEM PROJECT at St. Jude (Memphis, TN). 
Table 1. List of transcription factors assayed in the current study

\begin{tabular}{lll}
\hline Gene & Ventricular zone & Postmitotic zone \\
\hline Math1 & + (RL) & $+++($ EGL) \\
Mash1 & + & - \\
Neurogenin2 & + & $++($ SVZ) \\
Neurogenin1 & + & - \\
NeuroD & - & +++ \\
Dbx1 & - & - \\
Dbx2 & + & - \\
Lhx1 & - & +++ \\
Lhx5 & - & +++ \\
Lhx3 & - & - \\
Lhx2 & - & +++ \\
Lhx9 & - & +++ \\
Meis1 & - & +++ \\
Meis2 & - & +++ \\
Irx3 & +++ & +++ \\
Irx1 & +++ & ++ \\
Irx2 & +++ & ++ \\
Zic1,3 & +++ & + \\
Pax2 & - & +++ \\
\hline I, Lowest level of expression; ++++ & highest level of expression;,- no expression; ND, not done. SVZ, \\
Subventict &
\end{tabular}
Subventricular zone.

\section{Results}

Cell proliferation commences in the $\mathrm{VZ}$ of the cerebellar territory soon after neural tube closure. The earliest cerebellar progenitors exit the cell cycle in the VZ on approximately E10.25 (our unpublished results). At E11.5, the general postmitotic neuronal marker $(\beta$-Tub) reveals a zone of postneuronal precursors along the dorsal surface of the anlage; by E12.5, a second zone of postmitotic, $\beta$-Tub + cells forms beneath the superficial zone. Between E12.5 and E14.5, a secondary germinal zone, the anterior rhombic lip, begins to generate neuronal progenitors, which spread onto the surface of the thickening anlage. Thus, three primary zones of progenitor cells emerge in a step-wise manner in the embryonic cerebellum.

To define the expression patterns of TFs in the cerebellar progenitor populations, we combined BrdU incorporation with immunocytochemical localization of antibodies for transcription factors (Table 1). From E10.25 to E12.5, IRX3 and MEIS1 immunopositive cells were evident in the VZ and in the zone of postmitotic $\beta$-Tub + cells on the dorsal surface, suggesting that MEIS1 and IRX3, members of the TALE (three amino acid loop) superfamily of transcription factors, are expressed by both dividing and postmitotic progenitor cells (Fig. 1) (data not shown). MEIS2 and the LIM homeodomain containing transcription factors, LHX2/9, are also expressed in the developing cerebellum at these stages of development. At E12.5, MEIS2 and LHX2/9 expression is specific to the postmitotic dorsal precursor population with no expression noted in ventricular zone progenitors (Fig. 1 $A, D)$ (data not shown).

Classical ${ }^{3} \mathrm{H}$-birthdating studies (Pierce, 1975) provide evidence that cells born in this period are progenitors of the cerebellar nuclei. To confirm the identity of this progenitor cell population, we performed BrdU labeling experiments in combination with immunolocalization of MEIS2. Sagittal sections of E12.5 mouse embryos pulsed with BrdU at E10.25 showed large numbers of BrdU-labeled cells on the dorsal surface (Fig. 1C). The majority of the BrdU+ cells expressed MEIS2, indicating that prospective neurons born at E10.25 migrate from the VZ onto the surface of the E12.5 anlage. At E14.5, MEIS1, MEIS2, IRX3, and LHX2/9 expression is maintained in nuclear precursors and
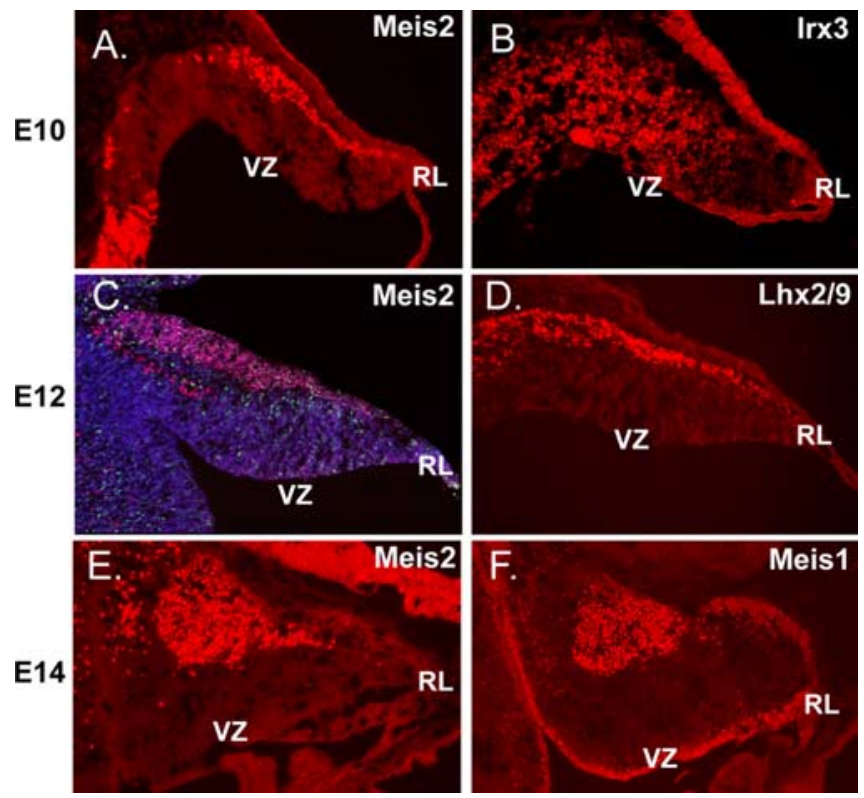

Figure 1. Precursors of the neurons of the cerebellar nuclei express the transcription factors IRX3, MEIS1, MEIS2, and LHX2/9. On E10.25, the initial progenitor population generated in the VZ lining the fourth ventricle gives rise to progenitors of the cerebellar nuclei. At this age, postmitotic cells are labeled with $\beta$-tubulin (data not shown). At E10.25 (A), MEIS2 cells are labeled on the surface of the developing cerebellar anlage. Irx3-positive cells are evident on the surface $(\boldsymbol{B})$ but also in transit from the VZ to the surface. By E12.5 (C), cells that exit the cell cycle on E10.25, as indicated by BrdU labeling ( $\boldsymbol{C}$, green), are located on the surface of the emerging cerebellar anlagen. Double labeling with antibodies against MEIS2 (red) confirms the expression of the transcription factor MEIS2; the total cell population is labeled with the marker $4^{\prime}, 6^{\prime}$-diamidino-2-phenylindole (blue). D, Labeling with antibodies against LHX2/9. By E14.5, cells labeled with antibodies against MEIS2 (E) and MEIS1 $(\boldsymbol{F})$ have migrated from the surface and begun to assemble into nascent cerebellar nuclei in the rostral aspect of the cerebellar territory.

marks the movement of these precursors into the aggregating cerebellar nuclei (Fig. 1E,F) (data not shown).

To assay the mode of migration of early nuclear progenitors from the ventricular zone to the dorsal surface of the anlage, we turned to Irx3-Egfp BAC transgenic mouse lines. Our aim was to examine whether radial glial fibers guide the radial migration of progenitors of the cerebellar nuclei from the VZ onto the surface during this early time period. In these assays, we stained transverse sections from Irx3-EGFP BAC transgenic mice with antibodies against EGFP and RC2. Similar assays were done using Meis2 antibodies in combination with RC2 staining. In control experiments, we demonstrated that $\mathrm{RC} 2+$ cells stretch across the thickness of the cerebellar anlage at E10.25, and that RC2 + cells double label with antibodies against BLBP at this stage (Feng et al., 1994; Anthony et al., 2004). By confocal imaging, MEIS2+ cells were closely apposed to RC2+ radial glial cells (Fig. 2A). Moreover, visualization of IRX3 + cells revealed a columnar arrangement of the progenitors of the nuclei migrating from the VZ to the surface along the radial glial fibers (Fig. $2 B$ ). Between E10.25 and E12.5, increasing numbers of IRX3 + neurons apposed to radial glial fibers (data not shown). Thus, the radial glial fiber system appears to provide the migratory pathway for the initial migration of cerebellar nuclear progenitors from the VZ to the surface of the anlage.

To further characterize patterns of gene expression and cell movement and to examine whether individual cells expressed combinations of transcription factors, we double labeled tissue sections from Egfp-BAC transgenic mice for each of the TFs stud- 

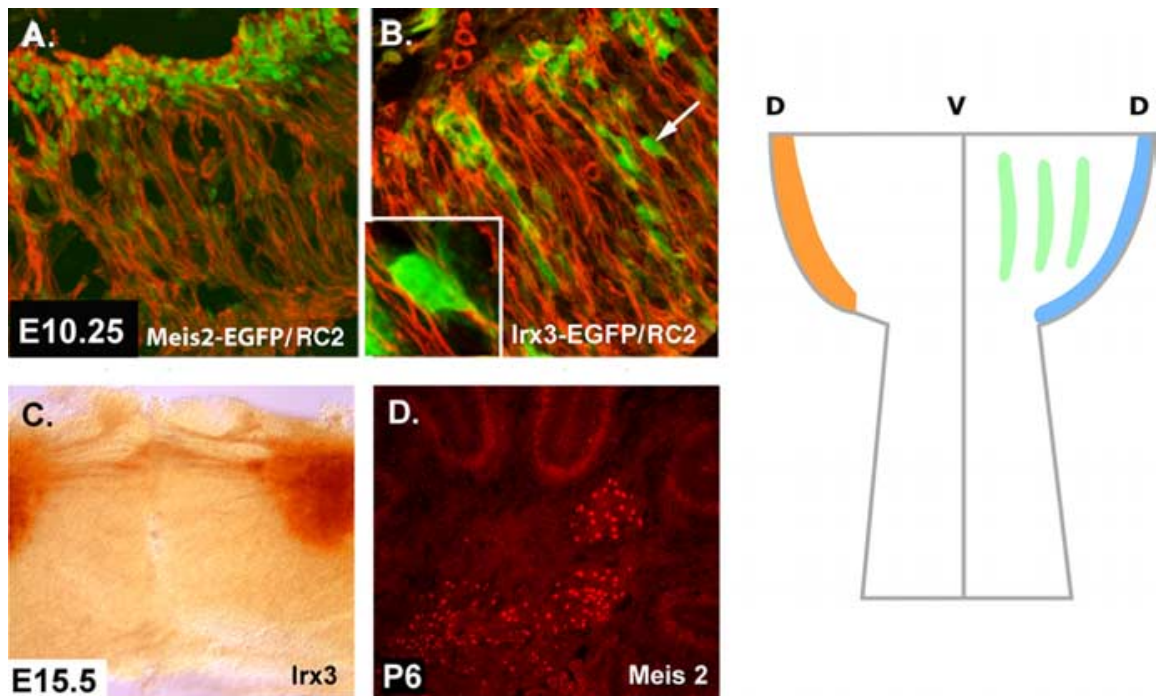

E15.5

Irx3

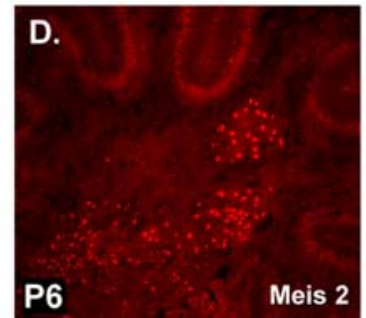

Figure 2. Migratory pathways of precursors of the neurons of cerebellar nuclei. At E10.25, the first precursors of the $\mathrm{CN}$ are migrating from the VZ to the surface of the anlagen. Double labeling with a marker for radial glia RC2 (red) and the EGFP reporter (green) on sections of Meis2-Egfp-BAC transgenic animals reveals a close apposition of migrating neurons to the radial glial pathway. In $\boldsymbol{B}$, similar results are observed with Irx3 + progenitors from /rx3-Egfp-BAC transgenic mice (green) and RC2 + radial glia. In the lower left area of $\boldsymbol{B}$, a high-magnification image of the cell marked with an arrow is illustrated. In $\boldsymbol{C}$, aggregating / $r \times 3+$ CN cells form distinct nuclei interconnected by fibers (EGFP labeling in Irx3-Egfp-BAC transgenic mice detected by DAB localization). In D, MEIS2 expression is illustrated in the cerebellar nuclei (immunostaining with antibodies against MEIS2). On the right, a general schema for the formation of the cerebellar nuclei is shown in a drawing of a whole mount of the midbrain/hindbrain region between E12.5 (left side of drawing) and E15.5 (right side of drawing). The dorsal surface of the cerebellar anlage is "D," and the ventral midline is "V." At the left, the orange zone on the dorsal surface is occupied by precursors of cerebellar nuclei progenitors on E12.5. By E 15.5, these cells exit the surface and form three distinct nuclei (green stripes); the EGL (blue) now occupies the dorsal surface.

ied. Immunostaining of E11.5 Irx3-EGFP BAC transgenic mice, with antibodies specific to EGFP and MEIS1, revealed doublelabeled cells in the VZ and in the zone on the dorsal surface. By E14.5, double-labeled cells were visible in the nascent cerebellar nuclei in the anterior cerebellum. Parallel experiments with $I r x 3$ BAC mice revealed numerous IRX3/MEIS2, IRX3/MEIS1, and $I R X 3 / L H X 2 / 9$ double-labeled cells within the emerging cerebellar nuclei in the anterior cerebellum (data not shown). Interestingly, double labeling was not uniform among the population of presumptive cerebellar nuclei progenitors cells, along the mediolateral axis. This suggests additional subpopulations of progenitors or different stages of development of progenitors within cerebellar nuclei.

Studies of BAC transgenic lines confirmed that the zone of nuclear progenitor cells migrated toward the rostral aspect of the anlage between E12.5 and E15.5. By E14.5, the population of Irx3+ cells left the surface and migrated inward to a position beneath the prospective zone of Purkinje cell precursors (see below). By E15.5, an Irx3+ axonal tract emerged from the medial deep nucleus toward the contralateral medial nucleus (Fig. 2c). At early postnatal stages, Irx3 and MEIS1- and MEIS2-positive cells were evident in the three-cerebellar nuclei (Fig. 2d) (data not shown). Thus, the combinatorial expression of Irx3, Meis1, and Meis2 delineates the progenitors of the cerebellar nuclei from their origin in the VZ to the formation of the nuclear structure in the neonatal cerebellum.

To examine whether the pattern of transcription factor expression observed for murine cerebellar nuclei progenitor cells was conserved in other vertebrates, we performed parallel studies in chick embryos. Chick offered the additional advantage of whole-mount preparations to trace formation of the cerebellar nuclei. In the E5 (HH24) chick cerebellum, staining of transverse sections shows LHX2/9, MEIS1, and IRX3 expression in postmitotic cells on the surface of the anlage (Fig. 3) (data not shown). To examine the formation of the cerebellar nuclei, we performed whole-mount in situ hybridization analysis with RNA probes specific to Irx3 and Meis1 at E7. Irx3 and Meis1 were expressed in two groups of cells aggregating to form the cerebellar nuclei in the depth of the cerebellar anlage (Fig. $3 E, F)$. Thus, parallel programs of transcription factor expression define the progenitors of the cerebellar nuclei in mouse and chick and the formation of the nuclear structure. Our studies of gene expression in hundreds of Egfp-BAC transgenic mice generated in the GENSAT program revealed other markers for neurons of the cerebellar nuclei, including Gap junction membrane protein $\alpha 9$ (Connexin-35) Gja9, a gene that is abundantly in developing brain, possibly because it characterizes weak electrophysiological connections, methyl-CpG binding domain protein (MBD2-Zinc finger) $M b d 2$, a transcriptional repressor, Serotonin receptor $3 a$ (Htr $3 a)$ and potassium inwardly rectifying channel (Kcnj5) (Fig. 4A-F). Each of these genes has potentially important functions in cerebellar development and should be useful tools for more detailed studies on the development of the structure and circuitry of the cerebellar nuclei.

\section{Neurons of the cerebellar cortex: Purkinje cells}

Although Purkinje cells begin to exit the cell cycle at approximately E11 (Miale and Sidman, 1961; Goldowitz et al., 1997), they do not express the classical postmitotic Purkinje cell marker Calbindin (CALB1) until E14.5 (Wassef et al., 1985). To identify TFs that mark earlier PC progenitors, we localized antibodies against transcription factors and then used Egfp-BAC transgenic mice to assay combinatorial expression patterns. At E11.5, antibodies against LHX1 and LHX5 labeled a small number of cells located just above the VZ. At E12.5, a large number of LHX1/5+ cells were located between the $\mathrm{VZ}$ and the superficial layer of cerebellar nuclei progenitors (Fig. $5 B, D$ ). Similar patterns were noted in early chick embryos (Fig. $3 B, D$ ). LHX1/5+ cells did not express MEIS1/2, IRX3, or LHX2/9 by double labeling assays (data not shown). This suggests differential patterns of transcription factors in progenitors of the cerebellar nuclei and Purkinje cells: the boundary of expression of transcription factors delineated zones of precursors of CN or PC cells.

To confirm the identity of Lhx1+ precursors, we immunostained cryostat tissue sections from E15.5, Egfp-Lhx1 BAC transgenic mice with a marker for Purkinje cells, CALB1. Although the vast majority of the Calb1+ cells double-labeled with Lhx1 (Fig. $5 C, D, E)$, a subpopulation of cells was $L h x 1+/ C A L B 1-$. The latter cells most likely represented postmitotic, Purkinje neuron progenitors that had not yet differentiated sufficiently to express CALB1. At E16.5, double labeling of $L h \times 5$ BAC transgenic mice with antibodies against EGFP and CALB1 also revealed double labeling in the vast majority of cells, confirming that $L h \times 5$ expres- 
sion marks Purkinje cells in the developing cerebellum (data not shown). Lhx5 expression persisted in Purkinje cells postnatally; after birth, $L h x 5$ was also expressed by cerebellar interneurons in the molecular layer and internal granule cell layer (Fig. 6C).

Although the development of Purkinje cells has been inferred previously using birth-dating techniques and molecular markers (Miale and Sidman, 1961; Altman and Bayer, 1985b; Feirabend et al., 1985; Yuasa et al., 1991; Millen et al., 1995; Lin and Cepko, 1998), absence of early markers for Purkinje cell precursors has precluded direct observations of their migratory pathway. In transverse tissue sections, LHX1/5+ cells closely apposed to $\mathrm{RC} 2+$ radial glia as they exited the VZ, beginning at E11.5 (Fig. 6A). Between E12.5 and E14.5 (Fig. 6C), numerous LHX1/5+ cells were evident along the RC2 + radial glial fiber system (Fig. $6 D)$. These results provide direct evidence for the long-standing assumption that immature Purkinje cells migrate away from the $\mathrm{VZ}$ along the radial glial fiber system.

We identified a remarkable new marker for both early Purkinje cell progenitors and mature Purkinje cells, RGS8, a GTPaseactivating protein, which modulates the kinetics of signaling by G-protein-coupled receptors. At E15.5, RGS8 is strongly expressed in PC precursors in the cerebellar anlagen (Fig. 7A). By P7, RGS8 is expressed in the cell soma, dendrites, and axons of Purkinje neurons (Fig. $7 B$ ). Although previous studies have examined RGS localization and function in cerebellar Purkinje cells (Saitoh et al., 1999; Jeong and Ikeda, 2001; Benians et al., 2004; Saitoh and Yoshihiro, 2004), our results provide the first evidence that RGS8 is an early marker of Purkinje cell differentiation. This suggests that G-protein-coupled receptors may function in Purkinje cell development, including axon extension and dendritic arborization. Similar expression patterns were observed using a BAC transgenic line for $P c p 2$, a gene expressed specifically in Purkinje cells within the developing brain (Fig. $7 C, D$ ) (data not shown).

The anterior rhombic lip: neurons of the cerebellar nuclei, the precerebellar nuclei, the vestibular nuclei, and the external germinal zone (EGL) of the cerebellar cortex.

To follow the emergence of progenitors from the aRL, we mapped the disposition of cells that express the transcription factor Math1 mRNA by in situ hybridization. By E12.5, Math1+ cells were observed in the aRL. Between E12 and E14, Math1+ cells spread across the surface of the developing cerebellum into the zone previously occupied by the progenitors of the cerebellar nuclei (Fig. 8). Meis1 also marked cells in the rhombic lip, migrating over the surface to form the EGL. A small number of Math1+ cells appeared to follow the MEIS1/IRX3/LHX2/9+ progenitors of the cerebellar nuclei, migrating across the surface and turning into the deeper layers of the anlage (data not shown). To examine whether a subpopulation of Math1+ granule cell progenitors also expressed MEIS1, we double labeled sections from a Math1-Egfp-BAC transgenic mouse line with antibodies against EGFP and MEIS1. At E16.5, when the cerebellar nuclear precursors have migrated to form the cerebellar nuclei, the vast majority of Math1+ cells in the EGL coexpressed MEIS1 (Fig. $8 E-G)$. These findings extend previous studies showing that Math1, Zic1, Zic3, and Pax6 and now Meis1 mark granule cell progenitors in the EGL (Ben-Arie et al., 1997; Nagai et al., 1997; Engelkamp et al., 1999).

Previous studies support the idea that Math1+ cells, which originate in the anterior rhombic lip, give rise to neurons in the precerebellar nuclei of the brainstem (Machold and Fishell, 2005; Wang et al., 2005). At E15.5, Math1-Egfp is abundantly expressed
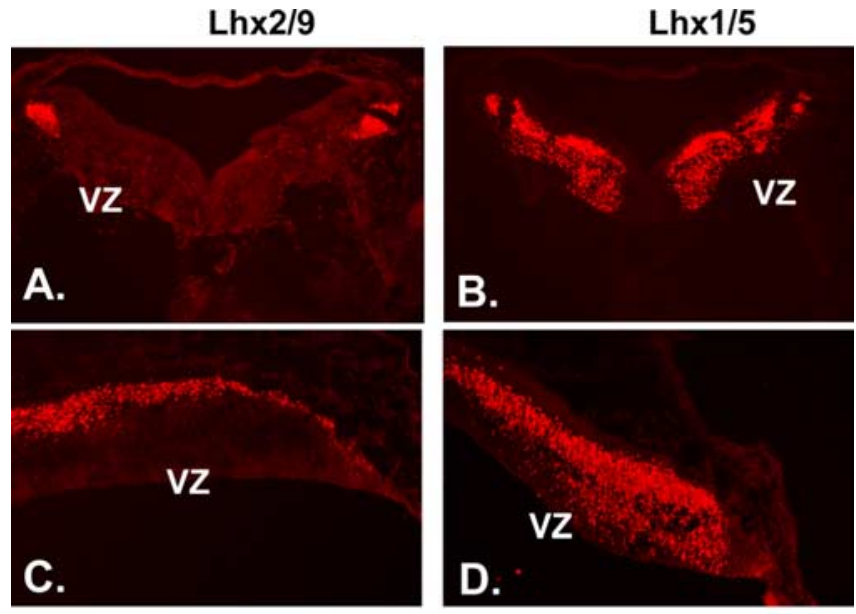

Flat-mount E7 - Ir $\times 3$

Flat-mount E7 - Meis1

E.

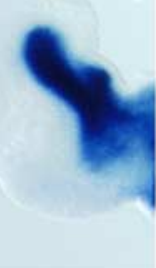

F.

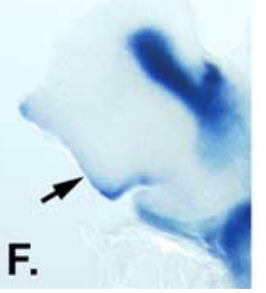

Figure 3. Expression of transcription factors in progenitor cell populations of the embryonic chick cerebellum. To examine whether the patterns of gene expression we observed were evident across species, we performed localization studies in embryonic chick cerebellum. In transverse sections at E4.5, antibodies against LHX2/9 label prospective cerebellar nuclear cells on the surface of the cerebellum $(\boldsymbol{A})$, and antibodies against LHX1/5 label cells in a zone beneath the cell surface $(\boldsymbol{B})$. In sagittal sections of E5 chick, LHX2/9 + cells are evident on the surface of the developing cerebellar anlagen $(\boldsymbol{C})$ and $\mathrm{LHX} 1 / 5 \mathrm{PC}$ precursors beneath the superficial zone occupied by CN progenitors ( $\boldsymbol{D})$. In flat mount preparations of E7 chick (see Fig. 2 for schematic), in situ hybridization with a probe for $I r \times 3(\boldsymbol{E})$ reveals that $I r \times 3$ transcripts are restricted to the cerebellar nuclei, whereas hybridization with a probe for Meis1 $(\boldsymbol{F})$ reveals that Meis1 transcripts are expressed in cerebellar nuclei and in the EGL on the dorsal surface at right (arrow).

in both the EGL of the cerebellar cortex, the basilar pontine nucleus, and the vestibular nucleus (data not shown). This result confirms and extends our previous observation that aRL cells migrate to the lateral pontine nucleus in chick (Wingate and Hatten, 1999) and further suggests that Math1 is expressed in the vestibular nucleus.

A second molecular marker shared by cerebellar granule cell precursors and neurons of the pontine nucleus is the gene phosphodiesterase1c (Pde1c). Pde1c is of particular interest, because it is expressed by granule neuron progenitors from E12 through adulthood. Pde1c is therefore a novel granule cell marker expressed at all stages of granule cell development. In addition, $P d e 1 c$ is expressed in the basilar pons, the primary source of mossy fiber inputs to granule neurons, and in the olivary nucleus, the source of climbing fiber inputs to Purkinje cells (Fig. 9B,D). Thus, Pde1c is expressed in both classes of inputs that drive Purkinje cell excitability, the mossy fibergranule cell-Purkinje circuit, and the climbing fiber projection to the Purkinje cells. Pcsk9 is also expressed in cerebellar granule cells and cells of the basilar pons. In the brain at P7, strong expression is visible in granule cell progenitors and the neurons of the pontine nucleus (Fig. 9A). At E15.5 (Fig. 9C), Pcsk9 expression is restricted to the EGL of the cerebellar anlage and the prospective pontine nucleus of the brainstem. Pcsk9 is the 

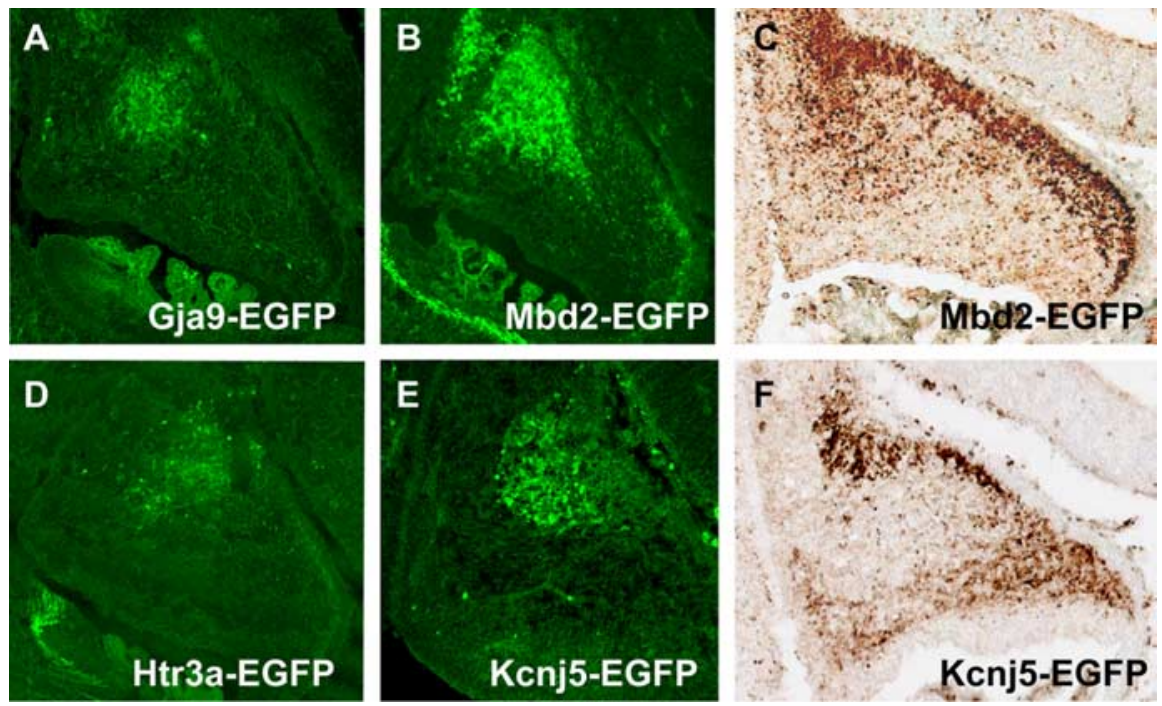

Figure 4. Markers for precursors of the neurons of cerebellar nuclei. Analysis of Egfp-BAC transgenic mice generated by the GENSAT project illustrates at least four markers for progenitors of the CN at E15.5. EGFP is expressed in cells located in the region occupied by precursors of the $\mathrm{CN}$ in the cerebellar territory of Gja9-Egfp BAC transgenic mice $(\boldsymbol{A}), M b d 2$-Egfp-BAC transgenic mice $(\boldsymbol{B}, \boldsymbol{C})$, Htr3a-Egfp-BAC transgenic mice (C), and Kcnj5-Egfp BAC transgenic mice ( $\boldsymbol{D}, \boldsymbol{E})$. As discussed previously, GJA9, a member of the connexin family, functions in temporary physiological connections, typical of embryonic neurons; MBD2 is thought to function in transcriptional repression; HTR3a is a serotonin receptor; and KCNJ5 is a potassium inwardly rectifying channel. $\boldsymbol{A}, \boldsymbol{B}, \boldsymbol{D}, \boldsymbol{E}$, Unstained sections; $\boldsymbol{C}, \boldsymbol{F}$, sections immunostained with antibodies against $\mathrm{EGFP}$ (DAB).

\section{E12.5 Lhx1,5}

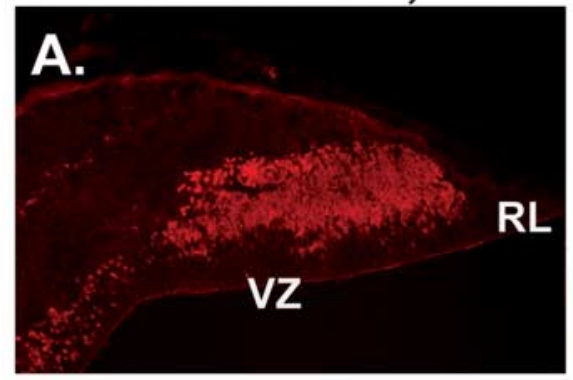

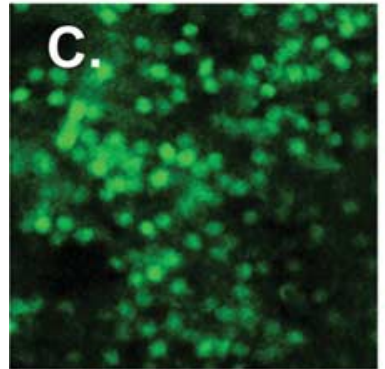

Lhx1-EGFP

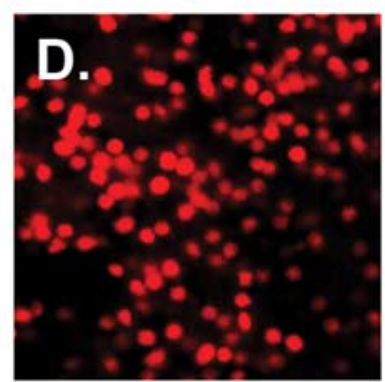

Calb1
E14.5 Lhx1,5
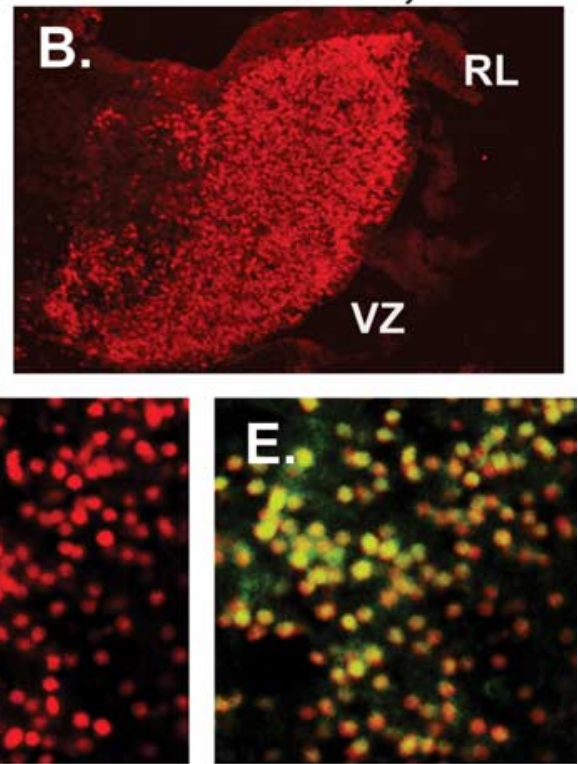

Merge

Figure 5. Purkinje cell progenitors express LIM homeodomain transcription factors. A, AtE12.5, PC progenitors that have exited the VZ express $L H X 1 / 5$. In $B, L H X 1 / 5$ expression continues as the number of $P C$ progenitors increases and forms a dense zone of cells beneath the dorsal surface of the anlagen. AtE14, the earliest stage at which $\mathrm{PC}$ progenitors express the signature $\mathrm{PC}$ marker CALB1 (C), EGFP + cells are evident in sections of $L h x 1$-Egfp-BAC transgenic mice in this zone. In D, staining with antibodies against CALB1 also reveals Purkinje cell progenitors, many of which are double labeled with EGFP $(\boldsymbol{E})$. Identical results were obtained in doublelabeling experiments with cells from Lhx5-Egfp-BAC mice (data not shown). Thus, Lhx 1 and $L h \times 5$ are expressed in progenitors of cerebellar Purkinje cells $2 \mathrm{~d}$ before expression of CALB1.

first example of a molecular marker for the lateral pontine nucleus, the primary source of mossy fiber afferents to the cerebellum, and the target of mossy fiber axons, the granule cell of the cerebellar cortex.

\section{Discussion}

The cerebellum is unique among brain regions, because it contains both a nuclear structure, typical of subcortical regions, and an overlying laminar cortex, typical of higher cortical regions. The present study provides evidence that the histogenesis of the cerebellum occurs via the stepwise generation of progenitor cells with restricted patterns of expression of TALE, LIM, and bHLH transcription factors, and coordinated movements of these populations to form the cerebellar nuclei and the overlying cerebellar cortex (Fig. 10). A particularly interesting aspect of this study is the multistep migration involved in the formation of the cerebellar nuclei, and the finding that progenitors derived from the rhombic lip generate precursor populations for both the cerebellar nuclei and the cerebellar cortex. The fact that progenitors of the anterior rhombic lip give rise to neurons of the precerebellar nuclei was first reported by Wingate and Hatten (Wingate and Hatten, 1999). Over the past several months, several molecular fate-mapping studies have extended those previous findings to include cells of the vestibular nucleus and precerebellar nuclei (Funfschilling and Reichardt, 2002; Landsberg et al., 2005; Machold and Fishell, 2005; Wang et al., 2005).

\section{The cerebellar nuclei}

Our gene expression profiles show that the onset of expression of TALE and LIM homeodomain transcription factors follows a precise temporal sequence in the embryonic cerebellum, in concert with the emergence of the three classes of cerebellar neurons (supplemental Fig. 1, available at www.jneurosci.org as supplemental material). Within the VZ germinal zone, expression of IRX3 and MEIS2 begins at E10, the time when classical studies by Sidman and colleagues showed that cell proliferation commences in the murine cerebellar territory (Miale and Sidman, 1961; Sidman, 1970; Pierce, 1975). The expression of LHX2/9 commences at E10.25, because the first wave of postmitotic progenitors delaminates from the epithelium lining the ventricle and moves above the VZ. Expression of LHX1/5 marked progenitor cells begins on approximately E11.5 in the zone just above the VZ.

An important aspect of the present study is the definition of a set of molecular markers to visualize the migratory pathways that establish the cerebellar nuclei. The cerebellar nuclei form in a 
four-step process: migration of postmitotic, IRX3/MEIS2/LHX2/9+ progenitors from the VZ to the surface of the anlage along the radial glial pathway; formation of CNP zone along the surface of the anlage; migration of CNPs from the surface to a position deep to the zone of immature Purkinje cells; and aggregation of CNPs into three distinct nuclei (two in chick). The coordinated expression of transcription factors provides insight into both the allocation of cell fates in the developing cerebellum and the complex migrations that establish the structure of the cerebellar nuclei. Although previous studies have suggested parallel plans of cerebellar histogenesis in mammals and birds, the present work provides the first evidence that similar molecular programs control the emergence of the three principal neural classes at the time when neurogenesis begins in the avian and murine cerebella. Moreover, the morphogenetic movements that drive the assembly of neurons into the cerebellar nuclei and overlying cerebellar cortex are similar in both model organisms.

This finding is of critical importance because of parallels in the development of the cerebellum and the cerebrum. The present study provides molecular evidence, consistent with the neuroanatomical literature, for the general idea that different combinations of transcription factors specify the principal classes of neurons in different brain structures. It will be interesting to examine whether parallels exist in the molecular pathways that specify progenitors of the cerebellar nuclei and progenitors of the basal ganglia of the cerebrum. Recent cellular and molecular fate-mapping studies of "the cerebellar system" (Millen et al., 1999), which includes the cerebellum and the precerebellar brainstem nuclei, reveal that the progenitor cell population, which emerges from the rhombic lip, is far more complex than previously recognized. Beginning with chick-quail fate-mapping experiments (Wingate and Hatten, 1999) and including recent elegant molecular fatemapping (Funfschilling and Reichardt, 2002; Landsberg et al., 2005; Machold and

Fishell, 2005; Wang et al., 2005; Farago et al., 2006), it is now evident that the EGL includes cells that have multiple fates. Within the developing cerebellar cortex, progenitors in the EGL give rise to granule neurons, one of the two principal neurons of the cortex. However, subpopulations of EGL cells, generated as early as E10.5 (Machold and Fishell, 2005), migrate from the surface of the anlage to generate progenitors of the cerebellar nuclei and to brainstem nuclei that project axons to the cerebellum. The new markers that we identified will aid in the further dissection of these progenitor subpopulations.

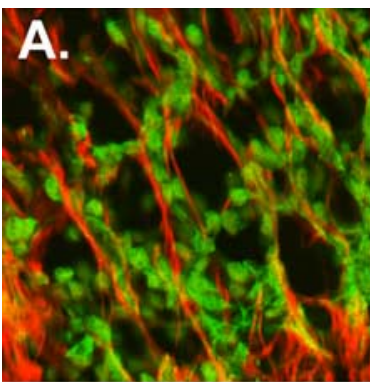

Lhx1-EGFP / RC2

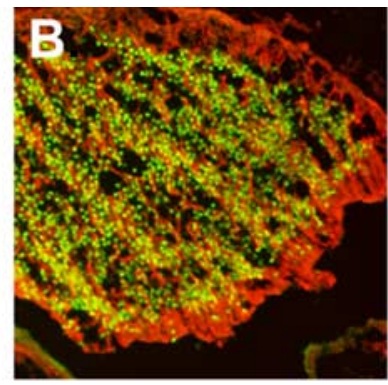

Lhx1-EGFP / RC2

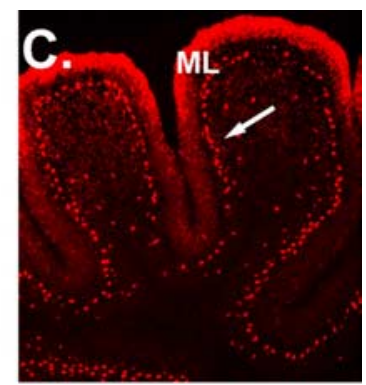

Lhx1-EGFP
Figure 6. Purkinje cell progenitors migrate on the radial glial scaffold. Although previous studies indicate that CALB1+cells migrate along VIMENTIN + fibers, CALB1 is a relatively late PC marker, and VIMENTIN labels both neuronal and glial fibers. In $A$, at E11.5, cells expressing EGFP in Lhx1-Egfp-BAC-transgenic mice migrate along RC2 + radial glial fibers. In $\boldsymbol{B}$, at lower power, large numbers of EGFP + cells associate with immunostained radial glial fibers, indicating that PC progenitors use the radial glial pathway for their migration from the VZ out into the middle of the emerging cerebellar anlagen (E14.5). In the neonatal cerebellum (C), antibodies against LHX1/5 proteins label both Purkinje neurons (arrow) and interneurons in the molecular layer (ML).
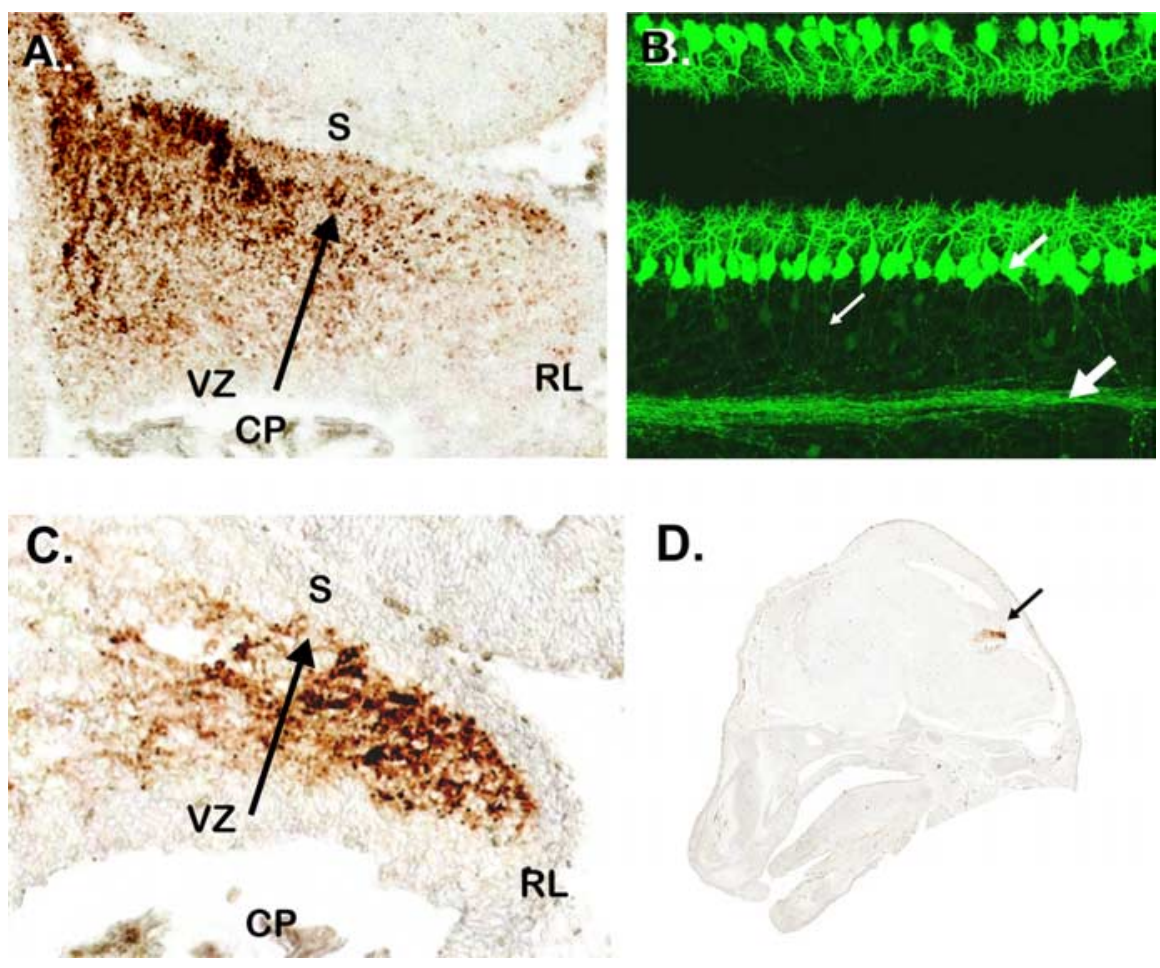

Figure 7. RGS8 is a marker for purkinje cell progenitors. Analysis of the Egfp-BAC transgenic mice generated in the GENSAT Project reveals expression of the RGS8 gene at E15.5 in cells thought to be precursors of Purkinje cells $(\boldsymbol{A})$. Fluorescence imaging of sections of Rgs8-Egfp-BAC transgenic mouse cerebellum at P7 reveals bright labeling of immature Purkinje cells $(\boldsymbol{B})$, their dendrites, and their axonal projections (arrows). In C, localization of the EGFP reporter gene in the cerebellar territory of $P(p 2$ 2-Egfp-BAC transgenic mice indicates robust EGFP expression in the zone occupied by immature Purkinje cells at this stage. $D$ indicates the restricted expression of the EGFP reporter gene for Pcp2-Egfp-BAC transgenic animals at E15.5, because cells other than PC progenitors in the emerging cerebellar territory are unlabeled. $C P$, Choroid plexus; $S$, surface.

The cerebellar system: genes that mark progenitors of the precerebellar nuclei and granule neurons

The expression of Math1 by neurons of the pontine nucleus is consistent with previous results with chick/quail chimeras showing that a subpopulation of progenitors in the EGL migrate ventrally to form the pontine nucleus, because Math 1 is expressed by neurons in the aRL. The expression of Math1 by pontine cells is of special interest, because precursors of the pontine nucleus exit the cell cycle before their ventral migration. In the cerebellar cortex, the MATH1+ EGL cells are dividing cells. 
Math1

E12.5

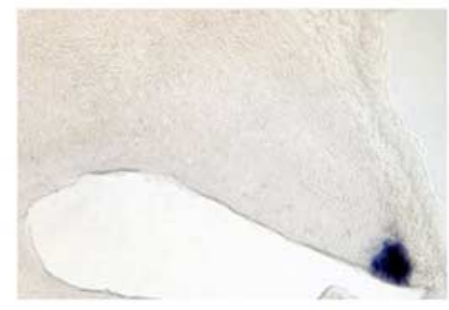

E14.5
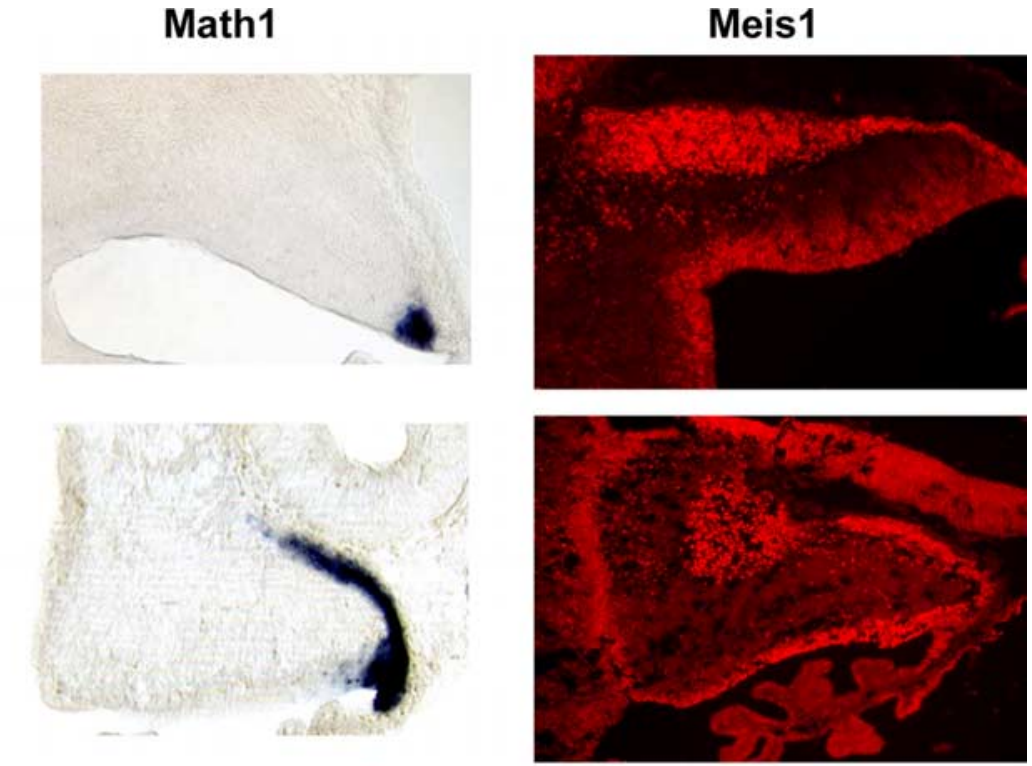

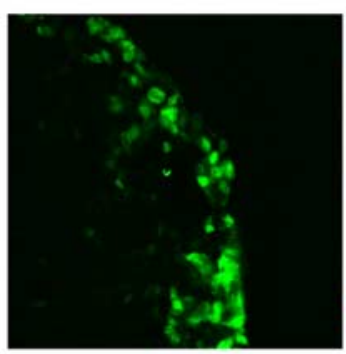

Math1- EGFP

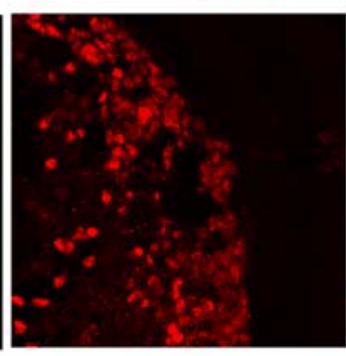

Meis1

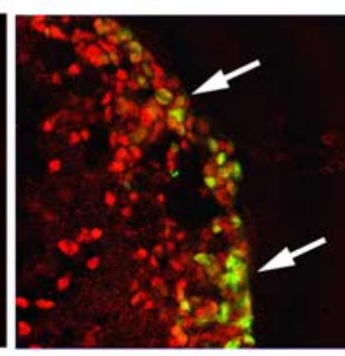

Merge

Figure 8. Meis1 expression by precursors of the CN and a subpopulation of EGL cells, which generate cortical granule neurons. Top, AtE12.5, Math1 expression is confined to the anterior RL, visible as the labeled, blue structure at the bottom right of the tissue (left). Antibodies against MEIS1 label precursors of the CN present on the surface of the anlagen and cells in the RL (right). Middle, By E14.5, Math1 + cells have spread across the surface of the anlage (left), and antibody staining reveals MEIS1 protein in the precursor cells, which are forming the $\mathrm{CN}$, visible as a large round domain of positive cells just beneath the surface in the medial aspect of the cerebellar anlagen and the emerging EGL, which covers most of the surface (right). Bottom, Immunostaining of the EGFP reporter in sections of Math1-Egfp-BAC transgenic animals to visualize EGFP illustrates a subpopulation of cells that are double labeled with antibodies against MEIS1 (arrows) in the EGL.

Pde1c is the second molecular marker shared by cerebellar granule cells and pontine neurons. Moreover, progenitor cells express Pde1c with a highly unusual migratory pathway in the embryonic neocortex. Like progenitors of the rhombic lip, Pdelc + cells in the embryonic neocortex migrate across the superficial aspect of the emerging cortical region.

In the early postnatal period, Pdelc is expressed in several brainstem nuclei that form connections with the cerebellum. Two major types of afferent axons project to the cerebellum: mossy fibers form connections with granule cells, and climbing fibers form connections with Purkinje cells. Mossy fibers originate in the precerebellar nuclei, which include the basilar pontine nuclei, the lateral reticular nucleus, and the reticular tegmental pontine nucleus; and areas that project mossy fiber collaterals to the cerebellum, including vestibular nuclei, the external cuneate nucleus, and cells in lamina VII of the spinal cord. Climbing fiber afferents to the cerebellar Purkinje cell originate in the olivary nucleus. In the neonatal and adult mouse brain, Pde1c is expressed in the pontine nucleus, a primary source of mossy fiber inputs and in the olivary nucleus, the source of climbing fiber inputs. Thus, Pde1c labels both afferent inputs to the granule cell, the synaptic target of the granule cell, the Purkinje neuron, and the afferent inputs to the Purkinje cell (Ito, 2006).

Pcsk9 also has a remarkable pattern of expression in embryonic murine brain (E15.5), because it only labels neurons of the pontine nucleus and granule neurons of the cerebellar cortex. Recent experiments indicate that repetitive firing of mossy fibers sets the level of intrinsic excitability of granule cells (Bower, 2002; Schmolesky et al., 2002; Boyden et al., 2004). In turn, granule cells modulate the dynamic range of Purkinje cell excitability via both excitatory input at parallel fiber synapses and inhibitory effects of the ascending granule cell axon (Bower, 2002; Boyden et al., 2004). Thus, mossy fiber inputs provide real-time modulation of Purkinje cell excitability. The restricted expression of Pcsk9 in one set of mossy fibers should facilitate more detailed analysis of the contribution of mossy fiber-granule cell firing on Purkinje cell function, including forms of Purkinje cell synaptic plasticity thought to control cerebellar function in motor learning and sensory discrimination (Thach et al., 1992; Lisberger, 1998; Schmolesky et al., 2002; De Zeeuw and Yeo, 2005)

\section{Purkinje cell development}

The Purkinje cell, because of its central role in cerebellar physiology, is one of the best-studied neurons in the vertebrate brain. Although extensive gene profiling has revealed as many as several thousand genes in postnatal Purkinje cells, insight on the earliest steps in Purkinje cell development has been lacking. The present study suggests a role for at least two members of the LIM homeodomain family of transcription factors $(L h x 1 / 5)$ in early steps in PC differentiation between cell cycle exit (E11.5-E13) and the expression of the "signature markers" Calb1 and Pcp2 (L7) (E14.5-E16). By in situ analysis, neonatal and adult Purkinje neurons also express high levels of $L h x 1$, suggesting that $L h x 1$ is a marker for Purkinje neurons from the time they exit the cell cycle in the cerebellar primordium throughout adulthood.

The present study used these early markers for Purkinje cell progenitors, combined with specific markers for radial glia, to demonstrate that early, postmitotic PC progenitors migrate away from the germinal zone along the glial fiber pathway. Previous studies were restricted to later stages (E15) after the onset of Calbindin expression (Batini, 1990). Moreover, previous studies used vimentin, a general marker for neuronal and glial fibers, rather than RC2 or BLBP, to label radial glia (Misson et al., 1988; Feng et al., 1994). The results on the migratory pathway of CNP and PCP (progenitor of the Purkinje cell), together with both classical and real-time imaging of granule cell migration, demonstrate that all three principal classes of cerebellar neurons undergo glial-guided migration. These results provide the impetus for studies to examine whether early steps in the development of 
A.

P7

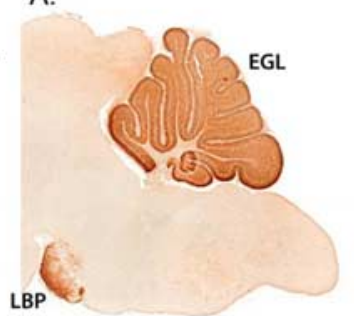

C.

E15.5

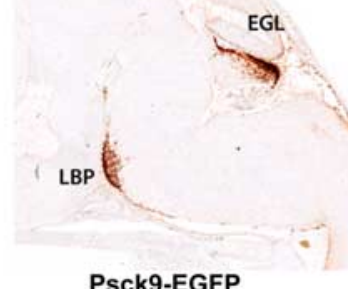

B.

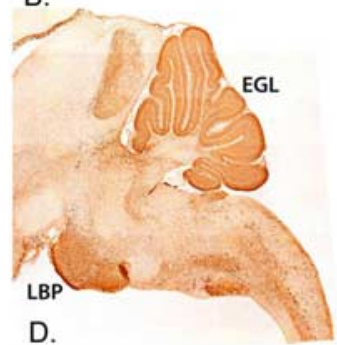

D.

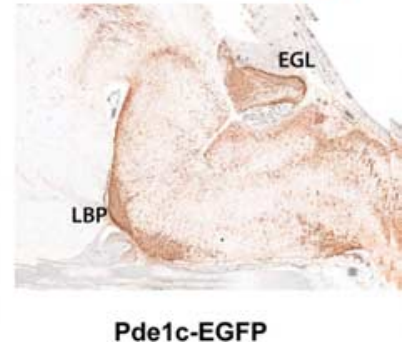

Figure 9. Genes expressed in the cerebellar EGL and in neurons of the lateral pontine nucleus. In the neonatal period, several genes are expressed in both the EGL, which will generate cortical granule neurons, and in neurons of the precerebellar nuclei in the brainstem, which form connections with granule cells. In $\boldsymbol{A}$, the EGFP reporter illustrates strong expression of the Pcsk9 gene in EGL cortical cells and in cells of the lateral basilar pons (LBP), a structure previously shown to be formed by aRL cells, which migrate ventrally (Wingate and Hatten, 1999). More importantly, the LBP projects mossy fibers to the granule cells, and the strength of the input from mossy fibers sets the level of parallel fiber output to the PCs. In the embryonic cerebellum, EGFP expression is restricted to the EGL of the cerebellar territory and the emerging LBP in the brainstem of Pcsk9-Egfp-BAC transgenic mice (C). Cerebellar EGL cells also express Pde1c, beginning on E10 in Pde1c-EgfpBAC transgenic mice (Gong et al., 2003). At P6 (B), the EGFP reporter is abundant in cerebellar EGL cells and in cells of both the lateral basilar pons and the olivary nucleus. This suggests that both the LBP cells, which project mossy fibers that form synapses with granule cells, and olivary neurons, which project climbing fibers that synapse with the targets of granule cells (Purkinje cells), express Pde1c. At E15.5, EGFP + cells from E15.5 Pde 1c-Egfp-BAC transgenic mice are evident in the cerebellar EGL, precursor neurons of the $C N$, the LBP, the olivary nucleus, and several other migratory pathways of rostral RL cells. As reported recently (Machold and Fishell, 2005; Wang et al., 2005), similar results are seen with EGFP labeling in Math1-Egfp-BAC transgenic mice where EGL cells, CN cells, basilar pons cells, and cells of other brainstem "cerebellar" nuclei contain EGFP + cells (data not shown).

the many nuclei of the cerebrum migrate away from the VZ along the glial fiber system, before tangential movements that assemble progenitors into subcortical structures.

The expression of RGS8 by Purkinje cells, at both embryonic and postnatal stages, is especially interesting, because RGS8 is thought to modulate G-protein receptor kinetics, including ion channels. RGS8 is expressed on both the dendritic arbors of Purkinje cells and on Purkinje cell axons. Moreover, it is expressed in early Purkinje cell progenitors, during the period when they are migrating from the VZ into the zone beneath the prospective EGL. Thus, RGS8 may function at early phases of Purkinje cell differentiation, as well as previously described functions in adult cerebellar cortex, where Purkinje cell RGS8 is thought to regulate the kinetics of G-protein-coupled receptor signaling and physiology (Saitoh et al., 1999; Jeong and Ikeda, 2001; Benians et al., 2004; Saitoh and Yoshihiro, 2004).

\section{Summary}

The present study shows that differential patterns of transcription factors define the three principal cerebellar neuron types: neurons of the cerebellar nuclei and Purkinje and granule cells of

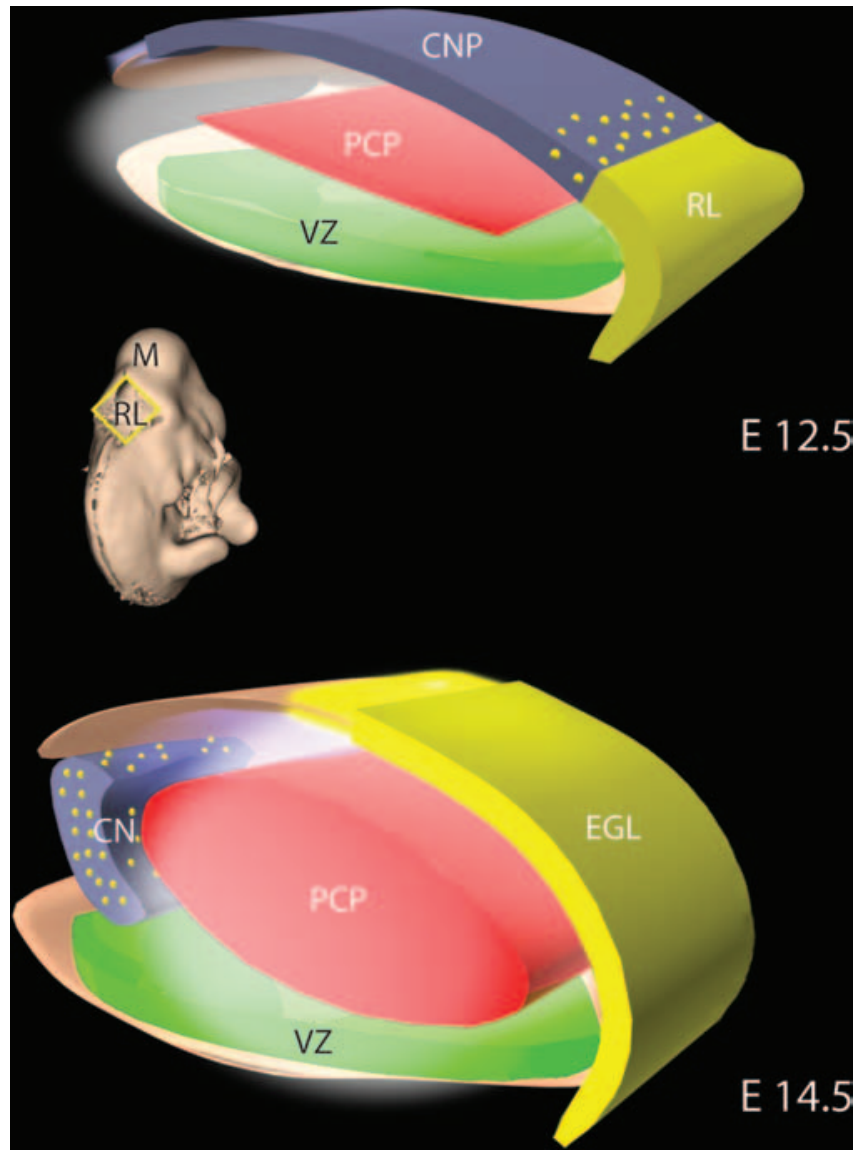

Figure 10. A model for the generation and migratory pathways of progenitors of the cerebellar nuclei. In the mouse, one population of progenitors of the neurons of the CNPS is generated in the VZ of the emerging cerebellar anlagen. Between E10 and E12.5, this progenitor population migrates radially along the glial fiber system (data not shown) to establish a superficial layer (blue). Subsequently, progenitors of the Purkinje cell (PCP) are generated in the VZ (E11-E14.5) and migrate radially to form a zone (red) beneath the CNPs. A second germinal zone, the anterior rhombic lip (yellow; RL), generates a subpopulation of precursors of neurons of the cerebellar nuclei, precerebellar nuclei (data not shown), and the granule neurons of the cerebellar cortex. At E12.5, a layer of CNPs (blue) generated in the VZ occupy the surface of the embryonic cerebellum. Between E12.5 and E14.5, several populations of RL progenitors move up onto the surface of the anlagen (yellow). These include the bulk of the progenitor population, the precursors of the granule neuron (solid yellow), and a subpopulation of cells that intercalate among the VZderived CNPs (yellow dots). By E14.5, the CNPs (containing both VZ and RL derived progenitors) have migrated off of the surface and formed the nascent cerebellar nuclei. By E16, the cerebellar nuclei (blue with yellow dots) settle beneath the emerging cerebellar cortex [containing the precursors of the granule neurons (EGL, yellow)], the Purkinje neuron (red), and the interneurons. Thus, a complex pattern of histogenesis and migration set forth the architecture of the murine cerebellum.

the cerebellar cortex. Together, these molecular markers illustrate several basic features of cerebellar development. First, the spatiotemporal expression of transcription factors combine with multistep migratory pathways of young neurons to generate the two fundamental structures of the cerebellum: the cerebellar nuclei and the cerebellar cortex. Given the parallels in the structure and function of the cerebrum (basal ganglia and cerebral cortex) and cerebellum (cerebellar nuclei and cerebellar cortex) (Thach et al., 1992; Fanselow and Poulos, 2005; Ito, 2006), our studies suggest that a deeper molecular understanding of the mechanisms of cerebellar development will provide new insights on the development and function of the cerebrum. The present study extends recent fate-mapping studies showing that the rhombic 
lip gives rise to progenitors for both the cerebellum and the structures that provide the afferent inputs for the cerebellar circuitry. The discovery of markers that begin to dissect distinct afferent pathways holds remarkable promise toward understanding the molecular development and plasticity of the cerebellar circuitry and its role in sensory discrimination and complex learning tasks involved in the fine control of balance and movement.

\section{References}

Alder J, Cho NK, Hatten ME (1996) Embryonic precursor cells from the rhombic lip are specified to a cerebellar granule neuron identity. Neuron 17:389-399.

Altman J, Bayer SA (1985) Embryonic development of the rat cerebellum. III. Regional differences in the time of origin, migration, and settling of Purkinje cells. J Comp Neurol 231:42-65.

Anthony TE, Klein C, Fishell G, Heintz N (2004) Radial glia serve as neuronal progenitors in all regions of the central nervous system. Neuron 41:881-890.

Batini C (1990) Cerebellar localization and colocalization of GABA and calcium binding protein-D28K. Arch Ital Biol 128:127-149.

Ben-Arie N, Bellen HJ, Armstrong DL, McCall AE, Gordadze PR, Guo Q, Matzuk MM, Zoghbi HY (1997) Math1 is essential for genesis of cerebellar granule neurons. Nature 390:169-172.

Benians A, Nobles M, Tinker A (2004) Participation of RGS8 in the ternary complex of agonist, receptor and G-protein. Biochem Soc Trans 32:1045-1047.

Bower JM (2002) The organization of cerebellar cortical circuitry revisited: implications for function. Ann NY Acad Sci 978:135-155.

Boyden ES, Katoh A, Raymond JL (2004) Cerebellum-dependent learning: the role of multiple plasticity mechanisms. Annu Rev Neurosci 27:581-609.

Cholley B, Wassef M, Arsenio-Nunes L, Brehier A, Sotelo C (1989) Proximal trajectory of the brachium conjunctivum in rat fetuses and its early association with the parabrachial nucleus. A study combining in vitro HRP anterograde axonal tracing and immunocytochemistry. Brain Res Dev Brain Res 45:185-202.

De Zeeuw CI, Yeo CH (2005) Time and tide in cerebellar memory formation. Curr Opin Neurobiol 15:667-674.

Dino MR, Schuerger RJ, Liu Y, Slater NT, Mugnaini E (2000) Unipolar brush cell: a potential feedforward excitatory interneuron of the cerebellum. Neuroscience 98:625-636.

Dymecki SM, Tomasiewicz H (1998) Using Flp-recombinase to characterize expansion of Wnt1-expressing neural progenitors in the mouse. Dev Biol 201:57-65.

Eccles J, Ito M, Szentagothai J (1967) The cerebellum as a neuronal machine. Berlin, Germany: Springer.

Engelkamp D, Rashbass P, Seawright A, van Heyningen V (1999) Role of Pax6 in development of the cerebellar system. Development 126:3585-3596.

Essick C (1912) The development of the nuclei pontis and the nucleus arculatus in man. Am J Anat 13:25-54.

Fanselow MS, Poulos AM (2005) The neuroscience of mammalian associative learning. Annu Rev Psychol 56:207-234.

Farago AF, Awatramani RB, Dymecki SM (2006) Assembly of the brainstem cochlear nuclear complex is revealed by intersectional and subtractive genetic fate maps. Neuron 50:205-218.

Feirabend HK, van Luxemburg EA, van Denderen-van Dorp H, Voogd J (1985) A 3H-thymidine autoradiographic study of the development of the cerebellum of the White Leghorn (Gallus domesticus): "evidence for longitudinal neuroblast generation patterns." Acta Morphol Neerl Scand 23:115-126.

Feng L, Hatten ME, Heintz N (1994) Brain lipid-binding protein (BLBP): a novel signaling system in the developing mammalian CNS. Neuron 12:895-908.

Fienberg AA, Utset MF, Bogarad LD, Hart CP, Awgulewitsch A, FergusonSmith A, Fainsod A, Rabin M, Ruddle FH (1987) Homeo box genes in murine development. Curr Top Dev Biol 23:233-256.

Fink AJ, Englund C, Daza RA, Pham D, Lau C, Nivison M, Kowalczyk T, Hevner RF (2006) Development of the deep cerebellar nuclei: transcription factors and cell migration from the rhombic lip. J Neurosci 26:3066-3076.

Fraser S, Keynes R, Lumsden A (1990) Segmentation in the chick embryo hindbrain is defined by cell lineage restrictions. Nature 344:431-435.
Funfschilling U, Reichardt LF (2002) Cre-mediated recombination in rhombic lip derivatives. Genesis 33:160-169.

Goldowitz D, Cushing RC, Laywell E, D’Arcangelo G, Sheldon M, Sweet HO, Davisson M, Steindler D, Curran T (1997) Cerebellar disorganization characteristic of reeler in scrambler mutant mice despite presence of reelin. J Neurosci 17:8767-8777.

Gong S, Zheng C, Doughty ML, Losos K, Didkovsky N, Schambra UB, Nowak NJ, Joyner A, Leblanc G, Hatten ME, Heintz N (2003) A gene expression atlas of the central nervous system based on bacterial artificial chromosomes. Nature 425:917-925.

Hallonet ME, Teillet MA, Le Douarin NM (1990) A new approach to the development of the cerebellum provided by the quail-chick marker system. Development 108:19-31.

Hamburger V, Hamilton HL (1992) A series of normal stages in the development of the chick embryo. 1951. Dev Dyn 195:231-272.

Hoshino M, Nakamura S, Mori K, Kawauchi T, Terao M, Nishimura YV, Fukuda A, Fuse T, Matsuo N, Sone M, Watanabe M, Bito H, Terashima T, Wright CV, Kawaguchi Y, Nakao K, Nabeshima Y (2005) Ptf1a, a bHLH transcriptional gene, defines GABAergic neuronal fates in cerebellum. Neuron 47:201-213.

Ito M (2006) Cerebellar circuitry as a neuronal machine. Prog Neurobiol 78:272-303.

Jeong SW, Ikeda SR (2001) Differential regulation of G protein-gated inwardly rectifying $\mathrm{K}(+)$ channel kinetics by distinct domains of RGS8. J Physiol (Lond) 535:335-347.

Joyner AL (1996) Engrailed, Wht and Pax genes regulate midbrain-hindbrain development. Trends Genet 12:15-20.

Joyner AL, Liu A, Millet S (2000) Otx2, Gbx2 and Fgf8 interact to position and maintain a mid-hindbrain organizer. Curr Opin Cell Biol 12:736-741.

Krumlauf R, Marshall H, Studer M, Nonchev S, Sham MH, Lumsden A (1993) Hox homeobox genes and regionalisation of the nervous system. J Neurobiol 24:1328-1340.

Laine J, Axelrad H (1994) The candelabrum cell: a new interneuron in the cerebellar cortex. J Comp Neurol 339:159-173.

Laine J, Axelrad H (2002) Extending the cerebellar Lugaro cell class. Neuroscience 115:363-374.

Landsberg RL, Awatramani RB, Hunter NL, Farago AF, DiPietrantonio HJ, Rodriguez CI, Dymecki SM (2005) Hindbrain rhombic lip is comprised of discrete progenitor cell populations allocated by Pax6. Neuron 48:933-947.

Lin JC, Cepko CL (1998) Granule cell raphes and parasagittal domains of Purkinje cells: complementary patterns in the developing chick cerebellum. J Neurosci 18:9342-9353.

Lisberger SG (1998) Cerebellar LTD: a molecular mechanism of behavioral learning? Cell 92:701-704.

Machold R, Fishell G (2005) Math1 is expressed in temporally discrete pools of cerebellar rhombic-lip neural progenitors. Neuron 48:17-24.

Martinez S, Crossley PH, Cobos I, Rubenstein JL, Martin GR (1999) FGF8 induces formation of an ectopic isthmic organizer and isthmocerebellar development via a repressive effect on Otx2 expression. Development 126:1189-1200.

Miale IL, Sidman RL (1961) An autoradiographic analysis of histogenesis in the mouse cerebellum. Exp Neurol 4:277-296.

Millen KJ, Hui CC, Joyner AL (1995) A role for En-2 and other murine homologues of Drosophila segment polarity genes in regulating positional information in the developing cerebellum. Development 121:3935-3945.

Millen KJ, Millonig JH, Wingate RJ, Alder J, Hatten ME (1999) Neurogenetics of the cerebellar system. J Child Neurol 14:574-581.

Misson JP, Edwards MA, Yamamoto M, Caviness Jr VS (1988) Identification of radial glial cells within the developing murine central nervous system: studies based upon a new immunohistochemical marker. Brain Res Dev Brain Res 44:95-108.

Nagai T, Aruga J, Takada S, Gunther T, Sporle R, Schughart K, Mikoshiba K (1997) The expression of the mouse Zic1, Zic2, and Zic3 gene suggests an essential role for Zic genes in body pattern formation. Dev Biol 182:299-313.

Nunzi MG, Birnstiel S, Bhattacharyya BJ, Slater NT, Mugnaini E (2001) Unipolar brush cells form a glutamatergic projection system within the mouse cerebellar cortex. J Comp Neurol 434:329-341.

Palay SL, Chan-Palay V (1974) Cerebellar cortex: cytology and organization. Berlin, Germany: Springer. 
Pierce ET (1975) Histogenesis of the deep cerebellar nuclei in the mouse: an autoradiographic study. Brain Res 95:503-518.

Rodriguez CI, Dymecki SM (2000) Origin of the precerebellar system. Neuron 27:475-486.

Saitoh O, Yoshihiro K (2004) Biochemical and electrophysiological analyses of RGS8 function. Methods Enzymol 390:129-148.

Saitoh O, Kubo Y, Odagiri M, Ichikawa M, Yamagata K, Sekine T (1999) RGS7 and RGS8 differentially accelerate G protein-mediated modulation of K+ currents. J Biol Chem 274:9899-9904.

Sanders TA, Lumsden A, Ragsdale CW (2002) Arcuate plan of chick midbrain development. J Neurosci 22:10742-19750.

Schmolesky MT, Weber JT, De Zeeuw CI, Hansel C (2002) The making of a complex spike: ionic composition and plasticity. Ann NY Acad Sci 978:359-390.

Shirasaki R, Pfaff SL (2002) Transcriptional codes and the control of neuronal identity. Annu Rev Neurosci 25:251-281.

Sidman RL (1970) Autoradiographic methods and principles for study of the nervous system with thymidine-H3. In: Contemporary research techniques of neuroanatomy (Nauta WJ, Ebbesson SOE, eds), pp 252-274. New York: Springer-Verlag.
Sotelo C (2004) Cellular and genetic regulation of the development of the cerebellar system. Prog Neurobiol 72:295-339.

Teune TM, van der Burg J, van der Moer J, Voogd J, Ruigrok TJ (2000) Topography of cerebellar nuclear projections to the brain stem in the rat. Prog Brain Res 124:141-172.

Thach WT, Goodkin HP, Keating JG (1992) The cerebellum and the adaptive coordination of movement. Annu Rev Neurosci 15:403-442.

Wang VY, Rose MF, Zoghbi HY (2005) Math1 expression redefines the rhombic lip derivatives and reveals novel lineages within the brainstem and cerebellum. Neuron 48:31-43.

Wassef M, Zanetta JP, Brehier A, Sotelo C (1985) Transient biochemical compartmentalization of Purkinje cells during early cerebellar development. Dev Biol 111:129-137.

Wilkinson DG, Bhatt S, Cook M, Boncinelli E, Krumlauf R (1989) Segmental expression of Hox-2 homoeobox-containing genes in the developing mouse hindbrain. Nature 341:405-409.

Wingate RJ, Hatten ME (1999) The role of the rhombic lip in avian cerebellum development. Development 126:4395-4404.

Yuasa S, Kawamura K, Ono K, Yamakuni T, Takahashi Y (1991) Development and migration of Purkinje cells in the mouse cerebellar primordium. Anat Embryol (Berl) 184:195-212. 